\title{
HERMENEUTIK AMINA WADUD; UPAYA PEMBACAAN KONTEKSTUAL TEKS KEAGAMAAN
}

\author{
Aspandi, Lc., M.H.I1
}

Institut Pesantren KH. Abdul Chalim Mojokerto

\begin{abstract}
Abstrak
Teks keagamaan diyakini sebagai hudan li annas yang mengandung nilai-nilai universal. Prinsip-prinsip universal diyakini relevan dalam setiap tempus dan locus. Asumsi tersebut berimplikasi bahwa prinsip-prinsip universal dapat dijadikan pijakan dan diimplementasikan dalam rangka menjawab problematika kontemporer dan tuntutan perkembangan zaman yang bersifat temporal dan partikular. Dalam sejarah perkembangan pemikiran hukum Islam, metode penafsiran teks keagamaan terus berubah dan berkembang. Dua dari banyak kecenderungan yang berbeda sering disebut sebagai pendekatan 'tekstualis' dan 'kontekstualis. Di era modern, pendekatan kontekstualis, sebagai sebuah alternatif, mulai mendapatkan perhatian. Para kontekstualis terlibat tidak hanya dalam analisis linguistik, tetapi juga mengadopsi pendekatan dari berbagai bidang seperti hermeneutika dan teori sosial. Amina Wadud merupakan salah satu tokoh yang dapat dikategorikan sebagai kontekstualis modern berusaha mengembangkan cara-cara baru untuk mendekati al-Qur'an.
\end{abstract}

Kata kunci: Kontekstual, Hermeneutik Tauhid

\section{PENDAHULUAN}

Pada jum'at 18 Maret 2005, masyarakat muslim dunia digemparkan oleh sebuah even yang meninggalkan diskursus hingga saat ini. Sekelompok orang laki-laki dan perempuan menyelenggarakan ibadah shalat Jum'at di sebuah gereja Anglikan, The Synod house of The Cathedral of St. John The Divine, New York, Amerika serikat. Seorang perempuan bertindak sebagai

${ }^{1}$ Dosen Institut Pesantren KH. Abdul Chalim Mojokerto 
imam sekaligus khatib dalam ibadah shalat Jum'at tersebut, dia adalah Amina Wadud Muhsin. Peristiwa tersebut memicu reaksi dari berbagai kalangan umat Muslim dunia. Ulama sekaligus Syekh al-Azhar di Mesir, Muhammad Sayyid al-Thanthawi mengkritik keras dan mengajukan keberatan atas aksi tersebut. Selain itu, Yusuf Qaradawi menyerang dan memvonis aksi Amina Wadud sebagai tindakan yang tidak Islami dan bid'ah. ${ }^{2}$ Aksi tersebut merupakan gambaran aksiologis pembacaan kontekstual Amina Wadud dalam teks keagamaan, dan upaya pencapaian gerakan gender equality di dunia Islam.

Amina Wadud berupaya melakukan "pembacaan kontekstual" dalam teks keagamaan yang bermakna bagi kehidupan kaum perempuan di dalam era modern kekinian. Dengan proses peninjauan ulang kata-kata yang terdapat di dalam al-Qur'an dan konteksnya, agar dapat memahami arti sebenarnya makna ayat (teks) al-Qur'an tersebut. Wadud menilai, setiap "pembacaan" merefleksikan, sebagiannya, maksud dari teks, dan "teks terdahulu" dari interpreter tersebut. Selain itu, pemahaman para reader terhadap satu teks yang sama akan menghasilkan pengertian yang berbeda. ${ }^{3}$ Dalam pandangan Wadud, tidak ada metode pembacaan teks keagamaan yang sepenuhnya obyektif. Setiap pembacaan membuat sejumlah pilihan yang sifatnya subyektif. Berbagai rincian pembacaan kadangkala mencerminkan pilihan subyektif para interpreternya, tanpa mementingkan maksud teks yang hendak diinterpretasikan. Disamping itu, Wadud menilai, banyaknya pemahaman yang sering tidak dibedakan antara teks dan produk interpretasi. ${ }^{4}$

2 Luthfi Asy-Syauanie, Gebrakan Amina Wadud, www. AsySyaukanie-com, dan Khaleed Abou El-Fadhl dalam "Foreword" atas buku Wadud., Inside the Gender Jihad: Women Reform's In Islam, vii.

${ }^{3}$ Amina Wadud, Al-Qur'an dan Perempuan, dalam Wacana Islam Liberal; Pemikiran Islam Kontemporer tentang Isu-isu Global (ed.) Charles Kurzman, Jakarta: Paramadina, 2003, 185-186.

4 Ibid., 186. 


\section{Aspandi | Hermeneutik Aminah Wadud}

Amina Wadud merupakan salah satu tokoh feminis Muslimah yang berusaha melakuan dekonstruksi dan rekonstruksi terhadap model pembacaan klasik yang dianggap syarat dengan bias patriarki. Isu mengenai kegelisahan yang dirasakan Wadud adalah fenomena patriarkal dalam masyarakat muslim. Wadud melihat marjinalisasi peran perempuan dalam tatanan sosial. Al-Qur'an yang menurutnya membawa nilai keadilan, belum mampu terasimilasi dalam kehidupan masyarakat muslim. ${ }^{5}$ Sehingga Wadud tidak ragu mempertanyakan bagaimana sebenarnya perempuan di perlakukan di dalam dunia Islam.

Salah satu asumsi dasar kerangka pemikiran Wadud adalah bahwa Al-Qur'an merupakan sumber nilai tertinggi yang secara adil mendudukkan laki-laki dan perempuan setara (equal). Selain itu, fakta bahwa pembacaan teks keagamaan klasik ditulis oleh eksklusivitas kaum pria. Hal ini menunjukan, bahwa selama perkembangan penafsiran Al-Qu'ran tidak terdengarnya keberadaan peran kaum perempuan dalam penafsiran. Hal ini berarti, pandangan dan pengalaman kaum prialah yang dimasukkan dalam penafsiran yang dilakukan tanpa partisipasi serta pandangan kaum perempuan. ${ }^{6}$ Wadud berasumsi, bahwa dalam proses pembacaan klasik, perempuan dan pengalamannya ditiadakan. Dengan kata lain, visi, perspektif, keinginan atau kebutuhan kaum perempuan ditafsirkan menurut pandangan kaum pria. ${ }^{7}$

Amina Wadud menaruh perhatian besar terhadap isu jender dalam pembacaan teks keagamaan. Wadud mengkritik

5 Amina Wadud, Inside the Gender Jihad: Women Reform's In Islam, England: Oneword Publications, 2006, 20.

${ }^{6}$ Amina Wadud, Qur'an and Woman: Rereading The Sacred Text From a Woman's Perspectif, Oxford: University Press, 1998, 187. Lihat juga, Marjoeri Procter Smith, In Her Own Rite: Recontructing Feminist Liturgical Tradition, Nashville, Tenn: Abingdon Press, 1991, 13-35, tentang signifikansi dimasukkan dan tidak dimasukkannya perempuan dalam dialog keagamaan.

${ }^{7}$ Amina Wadud, Al-Qur'an dan Perempuan, dalam Wacana Islam Liberal; Pemikiran Islam Kontemporer tentang Isu-isu Global, 187.

46 |Legitima : Vol. 1 No. 1 Desember 2018 
pembacaan klasik yang dianggap bias jender. Dalam pandangannya, munculnya gender inequality bukan karena teks, tetapi bias jender dalam penafsiran teks. ${ }^{8}$ Oleh karena itu, Wadud memberikan tawaran metodologis sebagai metode "pembacaan kontekstual" untuk menegaskan betapa kesatuan Al-Qur'an berlaku pada seluruh bagiannya.

\section{BIOGRAFI AMINA WADUD}

Amina Wadud memiliki nama lengkap Amina Wadud Muhsin. Terlahir dengan nama Maria Teasley, di Bethesda, Maryland Amerika Serikat pada 25 September 1952. ${ }^{9}$ Ayahnya seorang penganut Methodist dan ibunya keturunan Berber, Arab, dan Afrika. Ia memeluk Islam pada tahun 1972. Wadud memiliki lima anak, yang ia anggap sebagai saudara-saudara seiman.10

Wadud meraih gelar sarjana (B.S) pada tahun 1975 di University of Pennsylvania dalam bidang pendidikan. Gelar magister (M.A.) ia raih pada tahun 1982 di bidang Kajian-kajian Timur Dekat (Near Eastern Studies) di The University of Michigan, dan di universitas yang sama juga Wadud meraih gelar Doktor (Ph.D) pada tahun 1988 di bidang Kajian-kajian Keislaman dan Bahasa Arab (Islamic Studiea and Arabic). ${ }^{11}$ Ia juga belajar bahasa Arab di American University. Selain itu ia juga pernah belajar filsafat Islam di al-Azhar dan kajian tafsir al-Qur"ân di Cairo University, Mesir. ${ }^{12}$

Wadud banyak menguasai bahasa asing diantaranya, Inggris, Arab, Turki, Spanyol, Prancis, dan Jerman. Penguasaan Islam, 1.

${ }^{8}$ Amina Wadud, Qur'an and Woman, xii.

9 Amina Wadud, Inside the Gender Jihad: Women Reform's In

${ }^{10}$ Ahmad Baidawi, Tafsìr Feminis; Kajian Perempuan dalam alQur'ān dan Para Mufassir Kontemporer, Bandung: Nuansa, 2005, 109.

11 Dikutip dari curriculum vitae-nya di situs resmi Virginia Commonwealth University.

${ }^{12}$ www.wikipedia.com, diakses pada tanggal 15 Juni 2012

Legitima : Vol. 1 No. 1 Desember 2018 | 47 


\section{Aspandi | Hermeneutik Aminah Wadud}

banyak bahasa membuat Wadud banyak ditawari menjadi dosen tamu di berbagai universitas di antaranya, Harvard Divinity School (1997-1998), International Islamic Malaysia (1990-1991), Michigan University, American University di Kairo (1981-1982), dan Pensylvania University (1970-1975). Ia juga pernah menjadi konsultan workshop dalam bidang studi Islam dan gender yang diselenggarakan oleh Maldivian Women"s Ministry (MWM) dan Perserikatan Bangsa-bangsa (PBB) pada tahun 1999. Di luar aktivitas sebagai seorang feminis Wadud adalah seorang guru besar di Commonwealth University, Richmond Virginia.

Karya Wadud lebih banyak berupa artikel lepas di media dan jurnal-jurnal ilmiah. Karya dalam bentuk buku yang dapat dijadikan sebagai referensi utama kajian pemikirannya diantaranya; Qur'an and Woman: Rereading the Sacred Text from a Woman's Perspective yang terbit pada tahun 1999 dan Inside the Gender Jihad: Women's Reform in Islam yang terbit pada tahun 2006. Charles Kurzman dalam Liberal Islam ${ }^{13}$ menyatakan bahwa karya wadud Qur'an and Woman, muncul dalam suatu konteks historis yang erat kaitannya dengan pengalaman dan pergumulan para perempuan Afrika-Amerika dalam memperjuangkan keadilan gender. Karena selama ini, sistem relasi laki-laki dan perempuan di masyarakat memang seringkali mencerminkan adanya bias-bias patriarki. Sebagai impliksinya perempuan kurang mendapat keadilan secara lebih proporsional.

Adapun beberapa karya artikel yang dihasilkan oleh Wadud diantaranya adalah: "Muslim Women as Minority", Journal of Muslim Minority Affairs, London (1989); "The Dynamics of Male-Female Relations In Islam", Malaysian Law News (July, 1990); "Women In Islam: Masculine and Feminine Dynamics in Islamic Liturgy, Faith, Pragmatics and Development" (Hongkong, 1991); "Understanding the Implicit Qur"anie Parameters to the Role Women in the Modern Context" (1992); "Islam: A Rising

13 Charles Kurzman, Liberal Islam: A Source Book, New York: Oxford Uiversity Press, 1998, 127.

48 |Legitima : Vol. 1 No. 1 Desember 2018 
Responsse of Black Spiritual Activisme" (1994); dan "Sisters in Islam: Effective against All Odds, in Silent Voices Doug Newsom" (1995).

\section{KLASIFIKASI PEMBACAAN TEKS PERSPEKTIF AMINA WADUD}

Paradigma normatif berpandangan bahwa kebenaran "Teks" keagamaan bersifat immutable (kekal), namun kebenaran produk pembacaan teks bersifat relatif dan tentatif. Produk pembacaan merupakan muntaj al-fikr, produk pemikiran dari interpreters sebagai respons terhadap realitas teks. Sehingga ia dapat dikritisi, dan sangat mungkin "didekonstruksi" jika dianggap tidak relevan dengan tempus dan locus. ${ }^{14}$ Nasr Hamid Abu Zayd menekankan pentingnya dialektika antara rasio, teks dan realitas (waqi'). ${ }^{15}$ Proses dialektika inilah yang kemudian melahirkan ragam pembacaan dalam teks keagamaan. Dalam hal ini, Amina Wadud mengklasifikasi pembacaan teks keagamaan terkait masalah perempuan kedalam tiga kategori yakni; tradisional, reaktif, dan holistik.

Kategori pertama interpretasi teks terkait perempuan di dalam al-Qur'an disebut Wadud dengan istilah pembacaan "tradisional". Pembacaan ini memberikan interpretasi keseluruhan isi al-Qur'an, baik yang berasal dari era klasik maupun modern, dengan pokok bahasan tertentu yang dipilih oleh interpreternya. Pokok bahasan tersebut meliputi hukum, tasawuf, sintaksis-morfologis, balaghah, maupun sejarah. Pokok pembahasan tersebut menyebabkan perbedaan penafsiran. Dalam

14 Dekonstruksi merupakan tindakan subjek terhadap objek yang tersusun dari berbagai unsur, dalam rangka membongkar makna teks, membangun teks atau wacana baru dengan makna yang berbeda. Tujuannya antara lain, adalah untuk mempertanyakan dasar dan dampak, serta menolak kebenaran tunggal yang absolut. Lihat, Christopher Norris, Membongkar Teori Dekonstruksi Jacques Derrida, Yogyakarta: ar-Ruzz, 2003, 5-15.

15 Nasr Hamid Abu Zayd, Mafhum an-Nash: Dirasat fi 'Ulum AlQur'an, Kairo: al-Hay'ah al-Mishriyyah al-'Amanah li al-Kitab, 1993, 11.

Legitima : Vol. 1 No. 1 Desember 2018 | 49 


\section{Aspandi | Hermeneutik Aminah Wadud}

hal ini, Wadud menilai terdapat satu kesamaan pada karya pembacaan tradisional, yaitu metodologinya yang bersifat atomistik. ${ }^{16}$ Teks yang mengandung nilai universal gender equality dianggap telah ditakhsis atau bahkan dinaskh, sehingga keadilan bukan sesuatu yang berada dalam realitas dan rasional, melainkan berada dalam teks dan supra-rasional. sebagaimana Asma Barlas menyatakan bahwa, metodologi pembacaan tradisional bersifat generalisasi hal-hal yang partikular. ${ }^{17}$

Senada dengan pandangan Asma, Wadud menilai dalam pembacaan tradisional, nyaris tidak didapati metodologi yang menghubungkan hal-hal yang serupa, seperti ide, struktur sintaksis, prinsip-prinsip atau kesamaan tema. Akan tetapi, yang menjadi perhatian Wadud dalam pembacaan tradisional adalah bahwa pembacaan tersebut secara eksklusif merupakan karya kaum pria. Dalam pandangannya, Wadud menyatakan bahwa pembuatan paradigma dasar yang merupakan alat penelaah dan pembahasan al-Qur'an serta interpretasi Qur'ani, dilakukan tanpa partisipasi serta pandangan kaum perempuan sebagai pihak pertama. Tidak terdengarnya suara kaum perempuan selama periode kritis perkembangan penafsiran al-Qur'an bukannya tidak diperhatikan, tetapi secara keliru hal ini disamakan dengan ketidakberadaan suara kaum perempuan dalam teks al-Qur'an itu sendiri. ${ }^{18}$

Kategori kedua interpretasi tentang perempuan dalam teks al-Qur'an disebut oleh Wadud dengan istilah pembacaan "reaktif". Pembacaan ini banyak dipenuhi oleh reaksi para pemikir

16 Pendekatan atomistik adalah pendekatan penafsiran teks yang menerapkan beberapa makna sekaligus pada satu ayat, tidak mengembangkan suatu kerangka berdasarkan pemikiran yang sistematis untuk mengkorelasikan dan menunjukkan dampak pertalian yang sesuai dengan teks. Lihat Abdul Mustaqim, Epistemologi Tafsir Kontemporer, Yogyakarta: PT LKiS Printing Cemerlang, 2010, 67.

17 Asma Barlas, Cara Qur'an Membebaskan Perempuan, terj. R. cecep Lukman Yasin, Jakarta: serambi, 2003,hal 43-45.

18 Amina Wadud, Qur'an and Woman: Rereading The Sacred Text From a Woman's Perspectif, hal 1. 
modern terhadap sejumlah hambatan yang dialami kaum perempuan, baik sebagai individu maupun sebagai anggota masyarakat, yang menganggap bahwa sumber hambatan dan problematika kaum perempuan berasal dari teks al-Qur'an. Pada kategori pembacaan reaktif ini banyak interpreter perempuan dan atau orang yang menentang pesan al-Qur'an (dalam bahasa lain menentang Islam). Interpreters kategori ini lebih banyak menggunakan status perempuan yang rendah dalam masyarakat, sebagai pembenaran atas "reaksi" mereka. Dalam hal ini, Wadud menilai bahwa pembacaan kategori reaktif ini juga gagal menggambarkan perbedaan antara penafsiran dan teks al-Qur'an itu sendiri. ${ }^{19}$

Persoalan yang menjadi diskursus dan metode yang digunakan pada kategori pembacaan ini, sering kali berasal dari gagasan kaum feminis rasionalis. Meskipun para interpreternya yakni para pemikir modern, namun kerap kali menitikberatkan uraian mereka pada masalah-masalah yang absah. Akan tetapi tanpa didasari analisis al-Qur'an yang komprehensif. Sehingga kadang-kadang menyebabkan mereka mempertahanan dan membenarkan kaum perempuan berada pada posisi yang sama sekali tidak wajar, dengan asumsi bahwa hal tersebut sejalan dengan kedudukan perempuan di dalam al-Qur'an. Dalam hal ini, Wadud beranggapan bahwa pandangan ini harus diredam, dalam upaya membuat mulusnya langkah-langkah efektif untuk pembebasan kaum perempuan, yakni memperlihatkan hubungan antara pembebasan para perempuan dengan sumber utama

19 Wadud memberikan contoh Fatna A, yang mendiskusikan poin-poin yang valid dan memandang isu ini, namun pada saat ia mendiskusikan al-Qur'an, ia gagal dalam membedakan al-Qur'an dengan para penerjemahnya. Lihat, Fatna A (it) Sabbah dalam karyanya, "Woman in the Muslim Unconscious", diterjemahkan oleh Mary Jo Lakeland dari perancis, New York; Pergaman Press, 1984.

Legitima : Vol. 1 No. 1 Desember 2018 | 51 


\section{Aspandi | Hermeneutik Aminah Wadud}

ideologi dan teologi Islam, yang tidak lain adalah al-Qur'an itu sendiri. ${ }^{20}$

Kategori ketiga adalah pembacaan holistik. Dalam perspektif Wadud, pembacaan ini merupakan interpretasi yang mempertimbangkan kembali seluruh metode penafsiran al-Qur'an serta mengaitkannya dengan berbagai persoalan sosial, moral, ekonomi dan politik modern, termasuk masalah perempuan. Wadud menilai pembacaan holistik ini merupakan kategori pembacaan terbaik. Wadud berusaha menempatkan dirinya pada kategori ini. Wadud beranggapan kategori ini relatif baru dan tidak ada pertimbangan substansial mengenai isu-isu tertentu tentang perempuan dalam kaitannya dengan keseluruhan isi alQur'an dan prinsip-prinsip pokoknya. ${ }^{21}$

Dalam hal ini, Wadud berupaya membuat sebuah "pembacaan kontekstual" teks keagamaan yang di dalamnya terkandung pengalaman perempuan dan tanpa stereotip yang telah dibuat dalam kebanyakan kerangka interpretasi kaum pria. Wadud berupaya membuat sebuah "interpretasi" teks al-Qur'an dan berusaha menganalisis langsung makna teks al-Qur'an, dengan perlakuan terhadap masalah perempuan yang sangat berbeda dengan kebanyakan karya-karya yang ada mengenai topik serupa.

\section{HERMENEUTIK TAUHID: SEBUAH METODOLOGI PEMBACAAN KONTEKSTUAL}

Metode pembacaan Wadud pada dasarnya didasarkan pada kerangka pemikiran Fazlur Rahman, seorang perintis tafsir kontekstual yang terkenal dengan teori Double Movementnya. Dalam pandangan Rahman, persoalan metode dan pemahaman terhadap al-Qur'ân belum cukup dibincangkan dalam tradisi keilmuan Islam, dan hal ini merupakan perkara yang urgen untuk dikaji pada konteks kekinian. Corak pembacaan yang diwarisikan

20 Amina Wadud, Qur'an and Woman, 2.

${ }^{21}$ Ibid., 3.

52 |Legitima : Vol. 1 No. 1 Desember 2018 
oleh penafsiran klasik dianggap telah gagal memaparkan pesanpesan al-Qur'ân secara padu dan koheren. Hal ini di akibatkan oleh kaidah penafsiran ayat per ayat, serta kecenderungan terhadap penggunaan ayat-ayat al-Qur'ân secara atomistik. Kalangan mufassir dan umat Islam pada umumnya tidak dapat menangkap keterpaduan pesan al-Qur'ân yang dilandaskan atas suatu weltanschauung atau worldview (pandangan dunia) yang pasti. $^{22}$

Berdasar paradigma tersebut, Wadud meyakin bahwa dalam usaha memelihara relevansinya dengan kehidupan manusia, al-Qur'ân harus terus-menerus ditafsirkan ulang. Dalam konteks ini, Wadud menawarkan sebuah metode pembacaan kontekstual berbasis hermeneutika ${ }^{23}$ al-Qur'ân sebagaimana ditawarkan Fazlur Rahman. Salah satu tujuan Wadud menggunakan metode ini adalah menafsirkan ulang makna alQur'ân. ${ }^{24}$ Dalam perspektif wadud, tidak ada penafsiran yang definitif (no interpretation is difinitive). ${ }^{25}$ Selain itu, aspek prior texts (latar belakang, persepsi, dan kondisi) ${ }^{26}$ menjadi hal yang teramat penting dalam kerangka metodologi pembacaan Wadud. Prior texts memberi cakupan luas, sehingga tidak muncul anggapan bahwa pembacaan tertentu lebih benar dari pembacaan

22 Fazlur Rahman, Islam and Modernity, Chicago: University Press, 1982, 2-3.

${ }^{23}$ Hermeneutik tidak berusaha menetapkan dan menstabilkan makna tertentu dari teks, melainkan berasumsi bahwa makna dari sebuah teks adalah hasil dari pembacaan seseorang. Dalam proses eksegesis, kontekstualisme banyak dipengaruhi oleh hermeneutic modern, seperangat prinsip yang digunakan dalam interpretasi teks, dalam makna lain didefinisikan sebagai 'eksplorasi filosofis terhadap karakter dan kondisi yang dibutuhkan untuk mendapatkan pemahaman. Lihat, Farid Esack, Qur'an, Liberation and Pluralism, Oxford: Oneworld Publication, 1997, 50-51.

Islam, hal 7.

24 Amina Wadud, Inside the Gender Jihad: Women Reform's In

25 Ibid., 199.

${ }^{26}$ Amina Wadud, Qur'an and Woman, hal 8.

Legitima : Vol. 1 No. 1 Desember 2018 | 53 


\section{Aspandi | Hermeneutik Aminah Wadud}

yang lain, karena sikap tersebut menutup kontekstualisasi pembacaan teks sebagai solusi dalam upaya merespon problematika kontemporer kekinian.

Gagasan teori pemikiran Wadud dirumuskan dalam sebuah metode yang ia sebut sebagai "Hermeneutika Tauhid", Wadud berangkat dari asumsi dasar bahwa laki-laki dan perempuan berasal dari penciptaan yang sama. Sehingga dalam metodelogi pembacaannya, Wadud menekankan pentingnya pendekatan holistik, bahwa pada dasarnya kesatuan al-Qur'an mengatasi seluruh bagian-bagiannya. Salah satu tujuan metode ini adalah untuk menunjukkan adanya dinamika antara aspek universal dan particular dari teks al-Qur'an. Berbeda dengan pesan moral teks yang bersifat universal, teks-teks al-Qur'an sangat dibatasi oleh partikularitas tempus dan locus. ${ }^{27}$

Operasionalisasi metode hermeneutika tauhid Wadud, merupakan salah satu bentuk metode pembacaan teks keagamaan yang di dalam pengoperasiannya untuk memperoleh kesimpulan makna suatu teks, selalu berhubungan dengan tiga aspek dari teks tersebut, yakni; (1) Dalam konteks apa suatu teks diturunkan (diwahyukan); (2) Bagaimana komposisi tata bahasa (gramatika) teks tersebut (bagaimana pengungkapannya, apa yang dikatakannya) dan (3) Bagaimana weltanschauung atau pandangan dunia dari teks tersebut secara keseluruhan. Kesatuan ketiga aspek tersebut dalam pandangan Wadud dianggap dapat meminimalisir subjektifitas interpretasi dan lebih mendekatkan hasil pembacaan kepada maksud teks yang sebenarnya. ${ }^{28}$

27 Amina Wadud, Qur'an and Woman, 14-15.

28 Dengan gagasan dan pola yang sama, Nasr Hamid Abu Zayd mengemukakan metode yang ia sebut sebagai manhaj al-qira'ah assiyaqiyah, yang meliputi; (1) siyaq tartib an-nuzul yakni tataran konteks keruntutan pewahyuan (2) siyaq as-sard yaitu tataran konteks naratif, dan (3) at-tartib al-lughawi adalah tataran struktur kebahasaan. Disamping itu konteks keseluruhan sosio-historis dari masa sebelum turunnya wahyu. Lihat Nasr Hamid Abu Zayd, Dawa'ir al-Khauf: Qira'ah fi Khitab al-Mar'ah, Kairo: al-Hay'ah al-Mishriyyah al-'Amanah li al-Kitab, 2003, 180-183.

54 |Legitima : Vol. 1 No. 1 Desember 2018 
Konsep dasar hermeneutika tauhid Wadud dilandaskan pada Tauhid yang menjadi fondasi Islam merupakan prinsip equality dan kepaduan kosmis. Wadud berpandangan bahwa pada tataran teologis, tauhid berkaitan dengan ketuhanan yang transenden dan imanen, yakni keesaan Tuhan. Sedangan pada tataran etis, tauhid berhubungan dengan berbagai relasi dan perkembangan dalam realitas sosial dan politik, dengan menekankan pada kesatuan seluruh umat manusia di bawah Sang Pencipta Tunggal. Dalam perspektif Wadud, dalam konteks hubungannya dengan keesaan Tuhan, manusia merupakan komunitas tunggal global tanpa ada pembedaan atas dasar suku, ras, jender, tradisi keagamaan, dan aspek perbedaan lainnya. Satusatunya aspek yang membedakan dalam konteks tauhid adalah takwa, kesadaran moral yang tidak dapat dijangkau oleh penilaian manusia lain walaupun implikasi-implikasi eksternalnya dapat dilihat dengan jelas. ${ }^{29}$ Menurut Wadud prinsip tauhid sama sekali tidak mendukung penggunaan kekuasaan (superioritas laki-laki) atas kaum perempuan. ${ }^{30}$

\section{INTERPRETASI TEKS OTORITAS LAKI-LAKI ATAS PEREMPUAN}

Budaya patriarki yang dianggap bias andosentris, di mana laki-laki dan pandangan laki-laki diangap sebagai norma, telah menjadi tatanan yang mapan pada berbagai komunitas Muslim. Hal tersebut tidak lepas dari pendapat beberapa kalangan, bahwa Islam pada dasarnya merupakan variasi dari ideologi patriarki. Hadirnya pembacaan tekstual yang menilai bahwa al-Qur'an memberikan lebih banyak hak kepada laki-laki ketimbang perempuan. Hal tersebut dinilai oleh beberapa kalangan termasuk Wadud, sebagai faktor yang berpengaruh terhadap lahirnya suatu Islam, 28-29.

${ }^{29}$ Amina Wadud, Inside the Gender Jihad: Women Reform's In

30 Ibid., 81.

Legitima : Vol. 1 No. 1 Desember 2018 | 55 


\section{Aspandi | Hermeneutik Aminah Wadud}

budaya yang dibangun di atas struktur dominasi dan subordinasi laki-laki atas perempuan. Oleh karena itu, otoritas laki-laki atas perempuan dan kesetaraan gender merupakan salah isu utama dalam kajian pemikiran Islam kontemporer. Salah satu teks yang menjadi fokus dalam diskursus mengenai isu-isu tersebut, yaitu Al-Qur'an Surat An-Nisa' ayat 34 yang menyatakan:

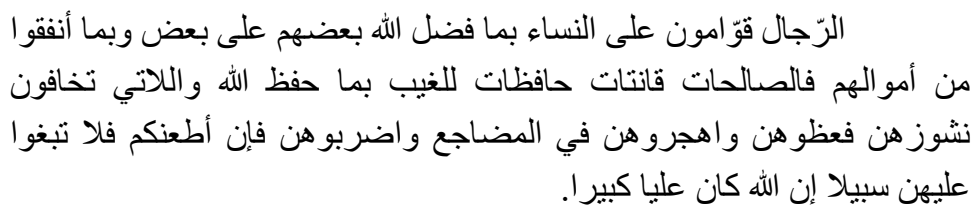

Kaun laki-laki itu adalah pemimpin bagi kaum wanita, oleh karena Allah melebihkan sebagian mereka (laki-laki) atas sebagian yang lain (wanita) [bima fadhala allahu ba'dahum 'ala $\left.b a^{\prime} d h\right]$ dan karena mereka (laki-laki) menafkahkan sebagian dari harta mereka. Sebab itu, wanita yang saleh [shalihat] ialah yang taat kepada Allah [qanitat] lagi memelihara diri [hafizhat li al-ghaib] ketika suaminya tidak ada, karena Allah telah memelihara (mereka). Wanita-wanita yang kamu khawatirkan nusyuznya, nasihatilah mereka. Kemudian jika mereka menaatimu, janganlah kamu mencari-cari jalan untuk menyusahkanna. Sungguh Allah Mahatinggi lagi Mahabesar.

Pembacaan tradisional, secara klasik menempatkan ayat tersebut sebagai satu-satunya teks paling penting yang berkaitan dengan hubungan antara laki-laki dan perempuan; "laki-laki merupakan qawwamuna 'ala (pemimpin-pemimpin bagi) perempuan-perempuan". Mufassir tradisional seperti Thabari menafsirkan teks (الرجال قوامون على النساء) laki-laki sebagai "pemimpin" (umara') atas perempuan. Berdasarkan beberapa riwayat yang terkait dengan frase pertama ayat tersebut, Thabari menyimpulkan bahwa ayat tersebut memberi para suami hak memikul tanggung jawab atas berbagai urusan kaum perempuan 
yaitu, hak untuk mendidik dan memerintah. Hal tersebut didasarkan pada kewajiban para suami untuk membiayai istri secara finansial, dalam bentuk mas kawin dan juga dalam kehidupan rumah tangga. ${ }^{31}$

Dengan pendekatan yang berbeda, Razi menunjukkan keberpihakannya pada otoritas laki-laki terkait ayat diatas. Razi mengidentifikasi dua alasan untuk qiwamah di pihak laki-laki, dengan mengikuti struktur ayat tersebut: pertama, keutamaan yang melekat ("dengan apa yang Tuhan telah anugerahkan kelebihan kepadanya atas yang lain"), kedua, berkait dengan finansial ("dengan apa yang mereka keluarkan dari harta mereka"). Razi memberikan identifikasi tentang kandungan makna kata fadhl. Bahwa laki-laki memiliki superioritas adalah sifat yang hakiki (sifat haqiqiyah). Sifat hakiki tersebut yang membuat laki-laki menjadi superior, baik dalam pengetahuan dan kekuasaan. Dalam pandangannya, laki-laki memiliki akal dan pengetahuan yang superior, karena itu laki-laki superior dalam hal intelektualitas, ketajaman, kekuatan, dan lainnya. ${ }^{32}$

Sebagaimana halnya Razi, lebih jauh Qurtubi memberikan beberapa alasan terkait keutamaan laki-laki atas perempuan. Qurtubi mengidentifikasi dua alasan sebagai legitimasi superioritas laki-laki atas perempuan, yaitu alasan keagamaan dan alamiah yang telah diberikan kepada laki-laki. Qurtubi mengqiyaskan dengan keutamaan ( $f a d h l)$; dan karenanya atas apa yang mereka keluarkan dari harta mereka. Selain itu, Qurtubi melakukan kajian kebahasaan atas lafal qawwam. Dalam

31 Abdullah Saaed, Reading the Qur'an in the Twenty-First Century A Contextualist Approach, New York: Routledge, 2014, 187.

32 Untuk memperkuat pendapatnya Razi menyajikan ragam contoh darimhukum agama atau adat istiadat terkait; (1) bahwa Para Nabi adalah laki-laki, (2) Laki-laki memiliki bagian lebih besar dalam harta waris, (3) Laki-laki memiliki kewajiban membayar diyat, kewajiban menjaga pernikahan, memiliki hak cerai, poligami, dan intisab (hak atas garis keturunan). Abdullah Saaed, Reading the Qur'an in the Twenty-First Century A Contextualist Approach, 190.

Legitima : Vol. 1 No. 1 Desember 2018 | 57 


\section{Aspandi | Hermeneutik Aminah Wadud}

pandangannya, bahwa lafal tersebut adalah bentuk intensif dari lafal qiyam. Dengan demikian, lafal tersebut bermakna "melaksanakan" sesuatu, memiliki satu-satunya hak untuk membuat keputusan terkait dengannya, dan berusaha menjaganya. Karena itu, qiyam pihak lai-laki diatas perempuan mencakup; mengurusi perempuan, mendidik, menjaga di dalam rumahnya, dan mencegahnya dari penampakan di ruang publik. ${ }^{33}$

Senada dengan Razi dan Qurtubi, Tabataba'I ulama modern Syi'ah berpendapat serupa bahwa laki-laki memiliki karakteristik alamiah tertentu seperti "rasionalitas yang lebih kuat ketimbang perempuan". Lebih jauh lagi, Tabataba'i menilai bahwa qiwamah laki-laki tidak hanya dalam konteks pernikahan, tetapi juga aspek-aspek lainnya, seperti hukum, politik, militer, dan sosial secara umum dari kehidupan manusia. ${ }^{34}$

Amina Wadud menentang sejumlah pembacaan konvensional, terutama mengenai penafsiran terhadap teks tertentu di dalam al-Qur'an, yang digunakan untuk membahas dan memenuhi fungsi al-Qur'an sebagai petunjuk universal. Berkaitan dengan fadldlala baik untuk laki-laki maupun perempuan, sebagaimana disebutkan dalam teks surat an-Nisa ayat 34, Wadud memberikan perhatian khusus pada kata $b i^{35}$ yang dipergunakan dalam ayat tersebut. Dalam analisanya, Wadud menyatakan bahwa di dalam sebuah kalimat, hal tersebut mengimplikasikan bahwa karakteristik atau isi sebelum kata bi adalah ditentukan "berdasarkan" apa-apa yang diuraikan setelah kata bi. Sehingga dalam ayat tersebut, kata bi berarti laki-laki qawwamuna 'ala (pemimpin-pemimpin bagi) perempuan-perempuan hanya jika

33 Abdullah Saaed, Reading the Qur'an in the Twenty-First Century A Contextualist Approach, 192-193.

34 Ibid., 198-199.

35 Kata bi dalam Bahasa arab berasal dari kata ba yang biasa disebut $\mathrm{Ba}$ al-sababiyah sebagai alasan atau pengajuan. Kata ini berdiri sebagai sebuah hubungan kondisional antara dua bagian dari sebuah kalimat atau anak kalimat. Bagian ini bersifat kondisional, dan tidak dapat dilambangkan tanpa bagian kedua.

58 |Legitima : Vol. 1 No. 1 Desember 2018 
disertai dua keadaan yang diuraikan berikutnya. Keadaan pertama adalah punya atau sanggup membuktikan "kelebihan"nya, dan yang kedua adalah jika mereka mendukung kaum perempuan dengan menggunakan harta mereka. Jika kedua kondisi tersebut tidak dipenuhi, maka laki-laki bukanlah pemimpin (qawwam) bagi perempuan. ${ }^{36}$

Dengan demikian, Amina Wadud menganggap bahwa qiwamah bersifat fungsional, merujuk kepada relasi fungsional yang secara ekonomi, sosio-kultural, dan historis bersifat kontingen dan tidak inheren (pada status suami). Sehingga qiwamah tidak terbatas pada hubungan finansial sebagaimana diinterpretasikan sebelumnya, tanpa gagasan apapun mengenai kepemimpinan laki-laki. Sebagaimana Riffat Hasan menilai, bahwa kalimat pertama Al-Qur'an surat 4:34 lebih bersifat normatif ketimbang deskriptif, karena tidak semua laki-laki menafkahi isterinya. ${ }^{37}$

Dalam perspektif Wadud, fadldlala tidak bias tek bersyarat karena surat an-Nisa ayat 34 tersebut tidak menyatakan "mereka" (jamak maskulin) telah dilebihkan atas "mereka" (jamak feminin). Ayat tersebut menyebutkan $b a^{\prime} d l$ (sebagian) di antara mereka atas ba'da (sebagian lainnya). Penggunaan kata $b a^{\prime} d l$ berhubungan dengan hal-hal yang nyata teramati pada manusia. Akan tetapi, tidak semua kaum pria unggul atas kaum perempuan dalam segala hal. Sebagian pria memiliki kelebihan atas sebagian perempuan dalam hal-hal tertentu. Demikian pula sebaliknya, perempuan juga memiliki kelebihan atas pria dalam hal tertentu. ${ }^{38}$

\footnotetext{
${ }^{36}$ Amina Wadud, Qur'an and Woman, 70.

37 Abdullah Saaed, Reading the Qur'an in the Twenty-First Century A Contextualist Approach, 202-203.

38 Wadud menterjemahkan kata $b a^{\prime} d l$ dalam maknanya yang biasa, yaitu "beberapa" atau "sebagian". Namun, di sisi lain, Wadud menggunakan kata " $b a^{\prime} d l$ "plus kata benda plural untuk pria (feminin) plus " $b a^{\prime} d l$ " yang berarti "satu sama lain", tanpa berimplikasi pada jender tertentu. Dengan kata lain, ada kesamaran makna yang mengelilingi
} 


\section{Aspandi | Hermeneutik Aminah Wadud}

Wadud berasumsi bahwa kelebihan yang ditetapkan oleh Syari' terhadap sesuatu atas lainnya, hal tersebut tidak berarrti maknanya bersifat absolut.

\section{SIGNIFIKANSI DAN KESIMPULAN}

Selain itu, signifikansi metode hermeneutika tauhid menurut Amina Wadud, tidak lepas dari pandangannya terhadap signifikansi bentuk maskulin dan feminin, baik yang digunakan untuk membedakan maupun yang bermakna umum, merupakan bagian penting dalam prosedur penetapan hukum. Perspektif tentang jender, khususnya pemahaman tentang perilaku yang digolongkan sebagai feminin dan maskulin serta peran laki-laki dan perempuan dalam masyarakat, didasarkan pada konteks budaya seseorang. Bahasa-bahasa berciri jender, seperti bahasa Arab, menciptakan prateks tertentu bagi para penggunanya. Hal tersebut menimbulkan perbedaan di antara beragam pembacaan teks al-Qur'an. Perbedaan tersebut tampak jelas dalam penafsiran teks dan kesimpulan-kesimpulan yang ditarik dari fungsi teks tersebut dalam kaitannya dengan jender.

Dengan gagasan hermeneutika tauhid, Wadud sesungguhnya menginginkan munculnya metode-metode baru dalam pembacaan teks keagamaan yang sesuai dengan kondisi masyarakat yang dihadapi, dengan tetap mempertahankan kesatuan dasar-dasar teks. Pentingnya mempertimbangkan qarâ`in ahwâl baik manqûlah maupun gairu manqûlah, dan kondisi sosial masyarakat akan selalu berubah dan berbeda, jelas mengandung makna dinamis dan dapat dikembangkan. Implikasinya, para interpeter haruslah merumuskan suatu metode alternatif dalam pembacaan teks untuk menyelesaikan persoalan-persoaan hukum kontemporer kekinian yang muncul dalam masyarakat.

pernyataan ini. Wadud beranggapan bahwa kata $b a^{\prime} d l$ juga dapat berarti, kaum wanita yang memiliki keunggulan atas kaum pria.

60 |Legitima : Vol. 1 No. 1 Desember 2018 


\section{DAFTAR PUSTAKA}

Abdullah Saeed, Reading the Qur'an in the Twenty-first Century A Contextualist Approach, New York: Routledge, 2014.

Abdul Mustaqim, Epistemologi Tafsir Kontemporer, Yogyakarta: PT LKiS Printing Cemerlang, 2010.

Ahmad Baidawi, Tafsìr Feminis; Kajian Perempuan dalam al-Qur'ān dan Para Mufassir Kontemporer, Bandung: Nuansa, 2005.

Amina Wadud, Inside the Gender Jihad: Women Reform's In Islam, England: Oneword Publications, 2006.

--Wadud, Qur'an and Woman: Rereading The Sacred Text From a Woman's Perspectif, Oxford: University Press, 1998.

-Wadud, Al-Qur'an dan Perempuan, dalam Wacana Islam Liberal; Pemikiran Islam Kontemporer tentang Isu-isu Global (ed.) Charles Kurzman, Jakarta: Paramadina, 2003.

Asma Barlas, Cara Qur'an Membebaskan Perempuan, terj. R. cecep Lukman Yasin, Jakarta: serambi, 2003.

Charles Kurzman, Liberal Islam: A Source Book, New York: Oxford Uiversity Press, 1998.

Christopher Norris, Membongkar Teori Dekonstruksi Jacques Derrida, Yogyakarta: ar-Ruzz, 2003.

Fatna A (it) Sabbah dalam karyanya, "Woman in the Muslim Unconscious", diterjemahkan oleh Mary Jo Lakeland dari perancis, New York; Pergaman Press, 1984

Fazlur Rahman, Islam and Modernity, Chicago: University Press, 1982.

Farid Esack, Qur'an, Liberation and Pluralism, Oxford: Oneworld Publication, 1997.

Marjoeri Procter Smith, In Her Own Rite: Recontructing Feminist Liturgical Tradition, Nashville, Tenn: Abingdon Press, 1991.

Nasr Hamid Abu Zayd, Mafhum an-Nash: Dirasat fi 'Ulum AlQur'an, Kairo: al-Hay'ah al-Mishriyyah al-'Amanah li alKitab, 1993.

Hamid Abu Zayd, Dawa'ir al-Khauf: Qira'ah fi Khitab alMar'ah, Kairo: al-Hay'ah al-Mishriyyah al-'Amanah li alKitab, 2003. 